\title{
TIGA JALAN ISLAM POLITIK DI INDONESIA: REFORMASI, REFOLUSI DAN REVOLUSI
}

\author{
Mohammad Iqbal Ahnaf \\ Dosen Center for Religious and Cross-cultural Studies (CRCS) Universitas Gadjah Mada \\ Jl. Teknika Utara, Pogung, Yogyakarta 55281, Indonesia. \\ E-mail: ahnafe7@yahoo.com
}

\begin{abstract}
Indonesia is often deemed unfavorable for political Islamic movements. This is prominently indicated by the fact that electoral achievement of parties with Islamic background has been historically lower than those of parties without stated association with Islamic groups. This is seen as a confirmation of the norm that Indonesian Islam is inherently moderate. This paper challenges such an argument because the up and down of political Islamc should not be primarily seen from thir electoral gains. This paper shows that political Islam in Indonesia is persistent and will continue posing a challenge to the dominant role of moderate Islam. Using different paths Islamist groups are competing for establishing ground in societies. This paper categorizes the paths chosen by political Islam in Indonesia into three models called reformist, 'refolutionist,' and 'staged revolutionary.' Islamic groups are categorized in the paper based on their political objectives and strategies.
\end{abstract}

Keywords:

Politics Islam; democracy; refolution; revolution

\begin{abstract}
Abstrak
Banyak analis meyakini bahwa Indonesia bukan lahan yang subur bagi politik Islam.Minimnya perolehan suara partai-partai Islam dalam setiap pemilu, dibandingkan dengan perolehan partai-partai nasionalis, dianggap sebagai indikator kegagalan politik Islam dan mencerminkan berakhirnya era politik aliran di Indonesia.Kesimpulan demikian seakan menegaskan bahwa karakter moderat Islam di Indonesia bersifat konstan atau permanen.Padahal kemajuan dan kemunduran politik Islam tidak hanya ditunjukkan oleh pencapaian elektoral partai Islam.Partai Islam hanyalah salah satu varian perjuangan politik Islam.Dengan penelitian kepustakaan dan metode penulisan deskriptif analitis, tulisan ini bertujuan untuk menunjukkan bahwa kegagalan elektoral partai Islam bukan berarti berakhirnya politik Islam.Politik Islam di Indonesia masih belum berakhir, hal ini dapat dilihat dari persaingan antara kekuatan moderat dan radikal di kalangan umat Islam dalam memperjuangkan politik Islam.Kesimpulan dari penelitian singkat ini menunjukkan bahwa ada tiga model Islam politik di Indonesia, yaitu: Islam politik reformis, Islam politik 'refolusioner', dan Islam politik 'revolusi-damai-berjenjang'. Di sisi lain, demokrasi di Indonesia akan menjadi peluang sekaligus tantangan bagi mobilisasi Islam politik radikal.
\end{abstract}

Kata Kunci:

Islam politik; demokrasi; refolusi;revolusi

DOI: http://dx.doi.org/10.15575/jw.v1i2.728

Received: March 2016 ; Accepted: July 2016 ; Published: July 2016

\section{A. PENDAHULUAN}

Ketika hasil pemilu tahun $2009^{1}$ dan $2014^{2}$ menunjukkan perolehan suara partai-partai

\footnotetext{
${ }^{1}$ Ada 44 Partai Politik pada Pemilu tahun 2009, dan 9 partai diantaranya saya anggap sebagai representasi partai Islam karena mengandalkanbasis kekuatan suara umat Islam (ada hubungan afiliasi ormas Islam). Perolehan suara nasional partai-partai tersebut pada pemilu 2009 adalah sebagai berikut: 8 . PKS: 7,88\% ; 9 . PAN: $6.01 \%$; 13. PKB: 4.94\%; 18. PMB: $0.40 \% ; 24$. PPP: $5.32 \%$; 27. PBB: $1.79 \%$; 29. PBR: $1.21 \%$; 34 PKNU: $1.43 \%$; 42. PPNUI: 0.14\%. ["Hasil Suara Nasional Pemilu 2009," 2009, diakses tanggal 5 Juli
}

Islam (kurang dari 35 persen) jauh di bawah

2015 ,

http://nasional.kompas.com/read/2009/05/09/22401496/ inilah.hasil.akhir.perolehan.suara.nasional.pemilu.]

${ }^{2}$ Ada 15 Partai Politik, 12 Partai Politik Nasional dan 3 Partai Politik Lokal/Aceh, pada Pemilu tahun 2014, dan 5 Partai dari 12 Partai Politik Nasional diantaranya saya anggap sebagai representasi Partai Islam. Perolehan suara nasional partai-partai tersebut pada pemilu 2014 adalah sebagai berikut: 2. PKB: 9.04\%; 3. PKS: $6.79 \%$; 8. PAN: 7.59\%; 9. PPP: $6.53 \%$; 14. PBB: 1.46\%. [“Hasil Pemilu 2014," 2014, diakses tanggal 5 Juli 2015, http://www.pemilu.com/hasilpemilu-2014/.] 
partai-partai nasionalis, banyak analis meyakini bahwa Indonesia bukan lahan yang subur bagi politik Islam. Kegagalan partaipartai Islam dianggap mencerminkan berakhirnya era politik aliran di Indonesia (the end of ideology). Kondisi ini dinilai menjadi puncak dari kegagalan politik Islam sepanjang sejarah politik Indonesia yang sudah mulai diperjuangkan sejak sebelum masa kemerdekaan. ${ }^{3}$ Kesimpulan demikian seakan menegaskan bahwa karakter moderat Islam di Indonesia bersifat konstan atau permanen. Gerakan yang menghendaki peran Islam secara luas dalam sistem hukum dan pemerintahan akan selalu membentur benteng tebal Islam mainstream NU dan Muhammadiyah, sebelum berhadapan dengan resistensi kekuatan non-Muslim di Indonesia.

Tulisan ini bermaksud menunjukkan bahwa kegagalan partai Islam bukan berarti berakhirnya politik Islam. Kemajuan dan kemunduran politik Islam tidak hanya ditunjukkan oleh pencapaian elektoral partai Islam. Partai Islam hanyalah salah satu varian perjuangan politik Islam. ${ }^{4}$ Persaingan antara kekuatan moderat dan radikal di kalangan umat Islam belum berakhir. Ketika batas komunal antara yang moderat dan radikal semakin kabur, sementara peran sosial kelompok mainstream melemah, bukan tidak mungkin peta (landscape) umat Islam akan berubah ${ }^{5}$. Pada bagian akhir akan ditunjukkan bagaimana demokrasi di

\footnotetext{
${ }^{3}$ Pandangan demikian misalnya diungkapkan oleh Bahtiar Effendi yang menegaskan kekalahan partai Islam pada pemilu 2009 adalah bukti kesekian bahwa Islam tidak lagi menjadi faktor penting dalam politik Indonesia. Politik partisan kehilangan relevansi di Indonesia. Lihat Bahtiar Effendy, "Islamic parties have long been at an impasse," Jakarta Post, 17 April 2009.

${ }^{4}$ Dalam paper ini politik Islam dipahami sebagai upaya mengintegrasikan kepentingan politik Islam berupa implementasi norma-norma hukum Islam dalam tatanan kenegaraan. Dengan cara pandang demikian politik Islam tidak selalu berarti Islam radikal. Sebagian aspirasi politik Islam bisa dipenuhi tanpa terjadinya perubahan politik secara radikal, tetapi pada tingkat ekstrem sebagian gerakan politik Islam menuntut perubahan secara radikal atau revolusioner.

5 Untuk ilustrasi awal tentang perubahan peta (landscape) umat Islam, lihat Ahnaf, Mohammad Iqbal,"Anticipating Changing Landscape of Muslims," Jakarta Post, 08 Nopember 2009.
}

Indonesia akan menjadi peluang sekaligus tantangan bagi mobilisasi Islam politik radikal.

Untuk memahami ragam Islam politik di Indonesia, termasuk membedakan yang radikal dan non-radikal, klasifikasi 5 tingkat tuntutan politik Islam yang dibuat Arskal Salim bisa memberi petunjuk ${ }^{6}$. Kelima tingkat tersebut mencakup: (1) Penerapan hukum Islam dalam masalah keluarga seperti perkawinan, perceraian dan harta waris; (2) Penanganan masalah dan lembaga keuangan seperti zakat, wakaf, dan perbankan Islam; (3) Penerapan hukum ta'zir untuk pelanggaran moral seperti konsumsi alkohol, perjudian, dan pelanggaran kewajiban seperti memakai jilbab; (4) Penerapan hukum hudud dan qisas untuk kasus perzinaan, pencurian, dan pembunuhan; (5) Tuntutan menjadikan Islam sebagai dasar negara dan sistem pemerintahan.

Perjuangan politik Islam tidak pernah berhenti dilakukan oleh ormas-ormas Islam. Sebagian besar sudah lama bergerak sejak masa-masa awal kemerdekaan, dan sebagian baru muncul belakangan terutama pascajatuhnya Soeharto.Performa gerakan-gerakan Islam ini mengalami pasang surut. Beberapa seperti Front Pembela Islam (FPI) dan Majelis Mujahidin Indonesia mengalami kemerosotan, kehilangan relevansi dan pengaruh; namun demikian konstituen politik Islam tidak sertamerta melunak karena sebagian gerakan Islam seperti Hizbut Tahrir Indonesia, Forum Umat Islam, dan kelompok gerakan Salafi mampu mengembangkan jaringan basis-basis sosial baru yang menerobos batas lingkaran Islam mainstream.

Berdasarkan strategi dan cakupan perubahan yang dikehendaki, gerakan politik Islam bisa dikelompokkan menjadi tiga: reformis, refolusioner, dan revolusioner. ${ }^{7}$ Klasifikasi ini tidak merujuk pada gerakan-gerakan yang

\footnotetext{
${ }^{6}$ Arskal Salim, Challenging Secular State: The Islamization of Law in Modern Indonesia (Honolulu: University of Hawai Press, 2008), 46.

${ }^{7}$ Ketiga istilah ini merujuk pada kategorisasi model perubahan politik yang digunakan oleh Janos Kis, dalam "Between Revolution and Reform" in East European Politics and Society, Vol. 12 (2), 2008, 300383.
} 
sepenuhnya terpisah (mutually exclusive). Meski memilih model gerakan yang berbeda, bisa jadi terjadi kolaborasi dan persinggungan antara satu dengan yang lain.

\section{B. HASIL DAN PEMBAHASAN \\ 1. Islam Politik Reformis}

Merujuk pada kategorisasi model perubahan sosial yang ditawarkan Janos Kis, ${ }^{8}$ saya menggunakan istilah reformis di sini dalam konteks universal, yakni perubahan yang terjadi secara parsial. Perubahan dilakukan melalui proses politik normal dalam kerangka sistem yang ada. Hal ini berbeda dengan penggunaan istilah reformis dalam konteks Indonesia yang merujuk pada dua hal: pertama, pembaharuan Islam Muhammadiyah berupa pemurnian akidah Islam dari praktik atau tradisi yang dinilai menyekutukan Tuhan, dan kedua, gerakan sosial yang mengakibatkan jatuhnya kekuasaan Soeharto.

Gerakan Islam politik reformis sebenarnya bermula dari tuntutan revolusioner untuk menjadikan Islam sebagai dasar konstitusi negara. Menjelang kemerdekaan Indonesia pada tahun 1945, tokoh-tokoh Islam dari beragam latar belakang termasuk NU dan Muhammadiyah menuntut posisi khusus Islam dalam konstitusi. ${ }^{9}$ Setelah perdebatan panjang, dengan jiwa besar sebagian besar tokok-tokoh Islam akhirnya merelakan tuntutan menjadikan Islam sebagai dasar negara. Hal ini dilakukan demi kepentingan bersama berdirinya negara Indonesia. Untuk menjaga keutuhan Indonesia sebagai negara dengan penduduk yang beragam, Pancasila disepakati sebagai dasar negara. Dengan Pancasila, Indonesia bukanlah

\footnotetext{
${ }^{8}$ Janos Kis, "Between Revolution and Reform"..., 300-383.

9 Perdebatan antara kubu Islam dan nasionalis tentang apakah Indonesia akan menjadi negara sekuler atau nasionalis tercermin dalam sidang BPUPKI pada tahun 1945. Tokoh-tokoh Islam yang awalnya menuntut Islam menjadi dasar negara diwakili oleh Abikusmo dan Agus Salim dari Sarekat Islam, Wahid Hasyim dari NU, dan Ki Bagus Hadikusmo dari Muhammadiyah. Lihat Noer, Deliar,Gerakan Modern Islam di Indonesia 19001942 (Jakarta: LP3ES, 1980), 307. Lihat juga, Boland, B.J.,The Struggle of Islam of Islam in Modern Indonesia (Martinus Nijhoff, The Hague, 1982).
}

negara agama sekaligus bukan negara sekuler. Sebagai penghargaan atas 'kemurahan hati' para pimpinan umat Islam, Departemen Agama dan Pengadilan Agama Islam dibentuk untuk mengakomodasi dan memfasilitasi kepentingan umat Islam. Melalui kedua lembaga ini, pemerintah mengakomodasi tuntutan administrasi politik umat Islam dalam perkara keluarga, seperti perkawinan, perceraian, warisan dan wakaf. Belakangan pemerintah juga mengatur aspek kepentingan umat Islam yang lebih luas berupa pendirian sistem perbankan Islam dan pembentukan lembaga amil zakat.

Mengikuti klasifikasi hirarki tuntutan politik Islam yang dibuat Arskal Salim, akomodasi kepentingan politik Islam sejauh ini masih mencakup dua tingkat pertama yang paling ringan, yakni pertama penerapan hukum Islam dalam masalah keluarga, kedua penerapan hukum Islam dalam masalah keuangan (perbankan Islam) dan zakat.

Namun demikian, sebagian kelompok Islam merasa akomodasi demikian tidak cukup dan menuntut memperjuangkan akomodasi dalam skala atau level yang lebih luas melalui proses dan dalam sistem politik yang ada. Beberapa agenda gerakan politik Islam dalam kategori ini antara lain adalah sebagai berikut:

1. Kampanye syariat secara umum.

2. Penerapan hukum ta'zir terhadap pelanggaran moralitas Islam melalui Peraturan Daerah (Perda).

3. Membangun kesadaran akan ancaman kristenisasi yang mengarah pada tuntutan pembuatan peraturan pemerintah yang membatasi aktivitas umat Kristen, seperti pembangunan gereja dan aktivitas sosial lembaga kemanusiaan Kristen.

4. Penentangan terhadap apa yang dianggap sebagai liberalisasi dan penyimpangan ajaran Islam dengan tuntutan pembatasan Negara terhadap penyebaran ide liberalisme, pluralisme, dan ajaran Ahmadiyah. Diantara kelompok atau lembaga yang berperan penting dalam lokus gerakan model ini adalah Forum Umat Islam (FUI) dan Majelis Ulama Indonesia (MUI). Kedua 
lembaga ini tidak selalu sejalan; kadangkala kolaborasi yang terjadi lebih bersifat individual tetapi seringkali membawa nama MUI. Namun demikian banyaknya tuntutan yang sama membuat kedua lembaga ini nampak sering bersama.

FUI adalah gerakan baru yang menghimpun tokoh-tokoh Islam dengan pemikiran yang beragam termasuk mereka yang meyakini pentingnya integrasi Islam dalam sistem kenegaraan dan mereka yang sekedar khawatir terhadap meluasnya kristenisasi, liberalisasi dan penyimpangan ajaran Islam. Jaringan organisasi FUI belum tersebar secara luas di berbagai daerah di Indonesia, tetapi FUI menunjukkan mampu membangun jejaring lintas-kelompok yang menembus batas lingkaran Islam mainstream di Indonesia. Banyak tokoh yang menggerakkan FUI duduk dalam struktur MUI dan berasal dari latar belakang Islam mainstream, NU dan Muhammadiyah. ${ }^{10}$ Gerakan FUI masih bersifat sporadis atau responsis terhadap isu-isu atau kasus-kasus tertentu yang dianggap berbahaya terhadap kepentingan politik umat Islam. Namun demikian belakangan FUI mulai membangun basis-basis sosial baru dalam bentuk aliansi-aliansi kecil pro-syariat yang secara reguler mempertemukan tokoh-tokoh Islam, seperti Forum Tokoh Peduli Syariat dan Dewan Syariat Kota. ${ }^{11}$

Gerakan Islam politik FUI-MUI juga sering bersinergi dengan kepentingan politik di daerah. Tumbuhnya Perda-Perda seputar

\footnotetext{
${ }^{10}$ Contoh gerakan FUI yang didukung oleh tokohtokoh MUI adalah Pembentukan Deklarasi Darunnajah di Pesantren Darunnajah, Jakarta, yang mengumpulkan sekitar 200 ulama, habaib dan tokoh Islam. Salah satu isi rekomendasi adalah dibentuknya tim yang akan mendorong penerapan solusi-solusi shar'iyyah terhadap berbagai masalah bangsa. Salah satu tokoh penting gerakan ini adalah ketua harian MUI pusat, K.H. Nazri Adlani yang juga ketua DPP Al-Ittihadiyah, ["Deklarasi Darunnajah,” 2008, diakses tanggal 03 Juni 2012, http://hizbut-tahrir.or.id/2008/08/02/deklarasidarunnajah/.]

11 Program pembentukan Dewan Syariat kota ini, misalnya, dibuat di Surabaya, yang menghimpun beragam tokoh untuk menyusun draf usulan peraturan tentang penerapan syariah Islam, lihat "Dewan Syariat Kota,” Al-Wa'ie, Edisi 64,Surabaya, 2005, 37.
}

kewajiban zakat, larangan perjudian, alkohol, dan kewajiban memakai jilbab di berbagai daerah tidak bisa dilepaskan dari sinergi kepentingan politik dan aspirasi politik Islam.

Selain keberhasilan politik dalam bentuk terwujudnya kebijakan-kebijakan Islami di daerah, pencapaian gerakan FUI-MUI juga ditunjukkan oleh kemampuan mereka membangun kesadaran politik Islam (politicized Islam) lintas kelompok. Jika jejaring ini terus bergulir, maka bisa berdampak pada mencairnya batas ideologis dan komunal antara Islam mainstream yang moderat dan Islam politik yang radikal. Cairnya batas ideologis ini akan menciptakan massa mengambang yang memudahkan mobilisasi dukungan terhadap Islam politik.

Namun demikian perlu diingat menyatunya beragam 'aliran' dalam aliansi Islam politik reformis dalam arus kekuatan FUI-MUI ini masih berada dalam koridor politik yang ada. Karena dua alasan kecil kemungkinan kekuatan ini akan bergerak ke arah ekstrem, paling tidak dalam waktu dekat. Pertama, keberadaan tokoh-tokoh dengan latar belakang yang beragam akan memaksa FUI untuk mengambil konsensus yang bersifat moderat. Tokoh-tokoh MUI seperti KH. Ma'ruf Amin dan Amidhan mewakili kekuatan moderat di dalam lingkaran aliansi di atas akan mendorong tokoh-tokoh radikal seperti Habieb Rizieq Syihab dan Muhammad Al-Khattath untuk tidak bergerak ke arah titik ekstrim; kedua perjuangan politik melalui institusi formal demokrasi akan menghalangi mereka untuk mengusung tuntutan radikal, berupa terciptanya tatanan hukum dan politik baru berdasarkan syariat.

\section{Islam Politik 'Refolusioner'}

Istilah 'refolusi' pertama kali digunakan oleh ilmuan politik Timothy Garton Ash untuk menggambarkan perubahan politik dari komunisme ke demokrasi di Polandia dan $\mathrm{Hu}-$ ngaria pada tahun 1983. Refolusi menggabungkan perubahan reformis dan revolutif. Tujuan akhir gerakan refolusioner adalah perubahan dalam skala luas yang berdampak pada perubahan tatanan sistem, namun dalam 
proses menuju tujuan akhir, pejuang refolusi terus mendesak perubahan secara gradual. Skenario perubahan refolusi terjadi melalui proses perubahan parsial (reformasi) secara terus menerus yang disertai dengan mobilisasi sosial kekuatan anti-kemapanan. Ketika kekuatan pro-perubahan mampu memobilisasi desakan publik yang begitu kuat, maka akan memaksa penguasa dan gerakan perubahan duduk di meja perundingan untuk membahas proses perubahan sistemik dengan mengganti konstitusi di mana unsur lama penguasa dan elemen pro-perubahan berbagi kekuasaan. ${ }^{12}$

Gerakan refolusioner dan reformis samasama memperjuangkan perubahan secara parsial dalam kerangka sistem yang berlaku. Yang membedakan keduanya adalah perjuangan para reformis dimaksudkan untuk memperbaiki sistem, sementara para refolusioner menerima perubahan parsial sebagai langkah delegitimasi terhadap sistem dan mendorong perubahan secara komprehensif.

Politik Islam refolusioner menjejakkan kakinya di dua arena, di luar dan dalam parlemen. Di satu sisi mereka menjelma menjadi partai politik, melakukan advokasi untuk terwujudnya legislasi dan kebijakan pemerintah yang berpihak kepada kepentingan Islam. Di sisi lain mereka melakukan mobilisasi sosial lewat halaqah dan penerbitan yang mengkampanyekan integrasi agama dan negara di mana hukum Islam diterapkan secara menyeluruh dalam berbagai aspek.

Dalam skala tuntutan politik Islam yang dibuat Arskal Salim, pejuang politik Islam refolusioner tidak cukup dengan akomodasi pada level pertama dan kedua; mereka secara terang-terangan menuntut tiga level terakhir yang bersifat radikal, yakni penerapan ta'zir, hudud-qisas dan menjadikan Islam sebagai ideologi atau sumber konstitusi negara.

Contoh gerakan model ini adalah Majelis Mujahidin Indonesia (MMI) yang didirikan oleh veteran gerakan Darul Islam DI, Abu Bakar Ba'asyir, yang bertujuan untuk mendirikan negara Islam yang terpisah dari

12 Ash, Timothy Garton, We the People: Revolution of 89, Witness in the Warsaw, Budapest, Berlin, and Prague (London: Penguin Books, 1990).
Indonesia. Meski pimpinan MMI tidak secara resmi mewarisi estafet kepemimpinan DI, bisa dikatakan MMI adalah transformasi DI, dari perjuangan militer menjadi perjuangan demokratis. Berbeda dengan DI yang memperjuangkan Negara Islam yang terpisah dari Republik Indonesia, MMI berjuang secara konstitusional untuk menerapkan syariat Islam secara komprehensif di Republik Indonesia. Tujuan ini mencerminkan unsur revolusioner dalam perjuangan MMI. Karena itu MMI menuntut perubahan total dengan mengusulkan draft Undang-Undang Dasar berdasarkan Islam yang mengatur seluruh aspek pemerintahan.

Namun demikian MMI tidak menentang perjuangan gradual atau reformis. Wujud perjuangan reformis MMI yang paling nyata adalah pembentukan lembaga advokasi Komite Persiapan Penerapan Syariat Islam (KPSI) yang bergerak pada tingkat lokal. Di beberapa daerah seperti Bulukumba, Tangerang, Padang, KPSI pernah berperan penting dalam mendorong terwujudnya perda-perda yang mengatur beberapa aspek dari tiga level syariat; tetapi belakangan peran mereka melemah kembali. Di banyak tempat anggota MMI bersama elemen Islam lain seperti HTI dan anggota MUI menjadi pelopor pendirian Forum Umat Islam.

Pengaruh politik MMI nampaknya masih sangat terbatas. Pemberitaan media yang mengaitkan MMI dengan organisasi teror Jemaah Islamiyah berperan penting dalam meminggirkan MMI dari arus utama perjuangan politik Islam. Basis kekuatan dan sentralisasi kepemimpinan MMI di Solo dan Yogyakarta membuatnya kekurangan basis sosial di tempat lain. MMI sempat menemukan saluran politik lewat KPSI dan aliansi sporadik seperti Forum Umat Islam Peduli Syariat yang muncul di berbagai daerah. Namun belakangan gerakan ini melemah akibat perpecahan internal atau karena kehabisan isu bersama yang menyatukan beragam kekuatan di dalamnya. Di Malang misalnya, Forum Umat Islam Peduli Syariat yang dipelopori 
pimpinan MMI dan HTI tidak bertahan lama ketika unsur HTI menarik diri. ${ }^{13}$

Gerakan politik Islam lain yang mempunyai jejak di arena parlemen dan extra-parlemen adalah gerakan Tarbiyah yang mewarisi Ikhwanul Muslimin. Melalui jejaring halaqah atau usroh dan Lembaga Dakwah Kampus (LDK), gerakan ini terus mengajarkan perlunya integrasi agama dan negara yang menerapkan hukum Islam secara menyeluruh. Halaqah dan LDK menjadi basis sosial yang menyiapkan sumber daya untuk perjuangan politik tarbiyah yang terserap oleh mekanisme demokrasi melalui Partai Keadilan Sejahtera (PKS). Tidak jelas apakah terjadi sinergi antara jejaring tarbiyah yang mengajarkan integrasi Islam dan negara dengan PKS yang menampakkan kecenderungan moderasi dalam arus demokrasi. Yang tidak bisa dipungkiri adalah banyak anggota PKS yang duduk di pemerintahan dan parlemen turut menjadi seringkali katalisator pembuatan kebijakan pemerintah yang mengutamakan kepentingan politik Islam. $^{14}$

Jika PKS menunjukkan kecenderungan politik yang semakin jauh dari idealisme Islam politik, bukan tidak mungkin jejaring Tarbiyah akan melepaskan diri dari 'ikatan' dengan perjuangan politik PKS. Dalam kondisi demikian, bisa terjadi dua kemungkinan, pertama mereka yang kecewa dengan PKS akan terintegrasi dalam apa yang disebut Oliver Roy gejala post-Islamism atau neo-fundamentalism yakni gerakan revivalis yang apolitis $^{15}$; kedua, bisa jadi jejaring Tarbiyah akan bertemu dengan gerakan extra-parlemen

\footnotetext{
${ }^{13}$ Pada bulan Agustus 2008, HTI mengeluarkan ta'mïm, pengumuman internal, yang menyerukan HTI secara organisasi menarik diri dari FUI (dokumen pribadi). Hal ini nampaknya diikuti oleh jajaran HTI di daerah.Di Malang HTI dan MMI mempelopori berdirinya Forum Umat Islam Peduli Syariat, namun belakangan pengurus mengakui perbedaan internal mengakibatkan organisasi ini tidak efektif. [Wawancara seorang tokoh HTI, oleh M. Iqbal Ahnaf di Malang, 28 Oktober 2009]

${ }^{14}$ Sebagai contoh salah satu kader PKS yang menjadi walikota Depok, Nur Mahmudi Ismail.

${ }^{15}$ Roy, Oliver, Globalized Islam: The Search for a New Ummah (Columbia: Columbia University Press, 2004).
}

HTI, apalagi keduanya mempunyai akar yang sama di LDK. Menjelang pemilu 2009 sempat muncul gagasan dari pemimpin FPI, Habieb Riziq Syihab, untuk mendirikan partai Islam ideologis. Partai demikian dimaksudkan untuk menjadi oposisi ideologis di parlemen sebagai alternatif terhadap partai politik Islam yang dianggap pragmatis. Dalam situasi saat partaipartai Islam melemah atau semakin pragmatis, bisa jadi gagasan seperti ini akan menampung kekuatan politik Islam yang menggabungkan perjuangan reformatif dengan visi revolusioner atau 'refolusioner'.

\section{Islam Politik Revolusi-Damai-Berjuang}

Baik refolusi maupun revolusi meyakini perlunya perubahan secara total terhadap sistem yang ada. Namun berbeda dengan refolusi yang masih percaya adanya jalan perubahan melalui mekanisme demokrasi, kaum revolusioner meyakini bahwa karena sistem demokrasi adalah sistem buatan manusia (bätii), maka perjuangan lewat jalan demokrasi tidak akan efektif. Karena tidak ada jalan lain, perubahan harus dimulai dengan merubah sistem atau revolusi.

Secara teoritis revolusi terjadi dalam dua kondisi. Pertama, jatuhnya penguasa (ruler) digantikan dengan penguasa baru (seizure of power), dan kedua diterapkannya sistem (rule) yang baru. Karena itu gerakan revolusioner berjuang dalam dua lokus secara bersamaan; yakni merongrong penguasa atau pemerintah dan delegitimasi atas perangkat (ide dan institusi) yang melanggengkan sistem yang ada. Mereka memilih jalan non-kooperasi karena bekerjasama dengan sistem berarti akan memperlambat runtuhnya sistem.

Contoh gerakan Islam yang mempunyai visi revolusioner adalah Hizbut Tahrir Indonesia (HTI). Organisasi ini adalah bagian dari gerakan internasional Hizbut Tahrir (HT) yang didirikan di Palestina pada tahun 1953 oleh seorang ulama ahli hukum Islam, Taqiyuddin al-Nabhani. Sebelum mendirikan HT, al-Nabhani dikenal sebagai ulama yang bersuara keras menentang penjajahan Barat di Timur Tengah. Ini tercermin dari dua buku kecil yang ia tulis sebelum mendirikan HT, 
Risalatul 'Arab (Seruan kepada Dunia Arab) dan Inqadu al-Filastin (Pembebasan Palestina); keduanya menyerukan persatuan dunia Arab untuk melawan penjajahan Barat. Kekecewaan terhadap kegagalan dunia Arab muncul terutama setelah kekalahan Arab dalam perang melawan Israel pada tahun 1948 yang mengakibatkan cengkeraman Israel atas Palestina. Kunci pembebasan Palestina adalah menghapuskan sekat-sekat negara bangsa (nation-state) di Timur Tengah.

Awalnya al-Nabhani $\bar{i}$ menyalurkan visi perlawanannya lewat sebuah gerakan nasionalisme Arab yang dekat dengan partai Ba'th di Jordania. Gerakan ini mempunyai tujuan revolusioner untuk menghapus sekat negara bangsa di Arab dengan menjatuhkan kekuasaan monarki di negara-negara Arab. Dengan dukungan seorang kolonel dari militer Jordania, Abdullah al-Tall, gerakan ini pernah berusaha melakukan kudeta untuk menjatuhkan kekuasaan raja Jordan, namun gagal. ${ }^{16}$

Setelah berinteraksi dengan partai Ba'th, alNabhani meyakini bahwa kelemahan gerakan Ba'th adalah karena ia didasarkan pada ideologi sekuler. Ia kemudian mendirikan partai politik Hizbut Tahrir yang bertujuan untuk menyatukan kekuatan Muslim sedunia dalam naungan satu kekuasaan Khilafah Islamiyah sebagaimana pernah tegak sejak masa Rasulullah hingga jatuhnya Khilafah Utsmaniyah pada tahun 1924.

Pada tahun tahun 1952, al-Nabhanī mendaftarkan Hizbut Tahrir sebagai partai politik ke pemerintah Jordania tetapi ditolak karena platform Hizbut Tahrir dianggap bertentangan dengan konstitusi Jordania. Setahun kemudian, 1953, al-Nabhani berusaha kembali mendaftarkan Hizbut Tahrir dengan dukungan dari gubernur Yerusalem tetapi kambali ditolak dengan alasan yang sama. Namun demikian, hal ini tidak menghentikan aktivitas Hizbut Tahrir yang terus melakukan mobilisasi bawah tanah penyebaran selebaran dan propaganda lewat ceramah-ceramah agama.

\footnotetext{
${ }^{16}$ Taji-Farouki, Suha,Fundamental Quest: Hizb alTahrir and the Search for Islamic Caliphate (UK: Grey Seals Books, 1997), 3.
}

Hingga sekarang Hizbut Tahrir tidak mendapatkan izin di banyak negara, terutama Negara-negara Arab. Namun demikian HT terus menunjukkan eksistensinya bahkan berkembang cukup pesat, terutama di negaranegara demokratis seperti Inggris dan Indonesia.

Ideologi Hizbut Tahrir mengajarkan strategi gerakan 'revolusi damai-berjenjang.' Meski demikian HT tidak secara terangterangan menyatakan bertujuan revolusi. AlNabhani menyatakan bahwa tujuan HT adalah 'melanjutkan kehidupan Islam' (instināf alhayät al-islämiyyah). ${ }^{17}$ Yang dimaksud kehidupan Islam adalah tegaknya daulah khilafah Islamiyah yang menyatukan umat Islam sedunia dalam kepemimpinan tunggal seorang khalifah yang tidak menerapkan hukum lain selain hukum Islam dalam berbagai aspek. Untuk menopang ideologi khilafah, literatur HT menghimpun berbagai sumber dari Alquran, Hadis dan buku-buku Islam klasik untuk mendukung argumen bahwa mendirikan khilafah hukumnya wajib bagi umat Islam.

Visi dan strategi perubahan yang diajarkan al-Nabhani jelas bersifat revolusioner. AlNabhani membedakan perubahan yang bersifat iṣlahị (parsial) dan inqilābi (total). Ia menentang upaya-upaya parsial atas problematika umat; menurutnya, karena masalah yang menyebabkan keterpurukan umat Islam bersifat mendasar yakni tidak diterapkannya Islam sebagai ideologi dan sumber hukum negara, maka perubahan harus bersifat fundamental, atau inqilāb shāmil. ${ }^{18}$

\footnotetext{
${ }^{17}$ Hizbut Tahrir, Hizb al-Tahrir (t.k.: Hizbut Tahrir, 1953), 6 .

${ }^{18}$ Visi revolusioner ini terlihat dari kutipan dari alNabhanini berikut: "Dunia Islam saat ini adalah dunia kafir karena meninggalkan pemerintahan Islam. Karena itu sebagian besar umat Islam melihat dunia Islam telah tercemari dan memerlukan reformasi (islāh). Namun demikian reformasi berarti menghilangkan noda kotor dari situasi saat ini. Ini tidak tepat karena dunia Islam saat ini memerlukan perubahan yang bersifat komprehensif dan radikal (inqilāb shämil) yang akan menghapus sistem kufur dan memperjuangkan pemerintahan Islam. Reformasi hanya akan mendorong pencemaran ajaran Islam," lihat Taqiyuddin Al-
} 
Dalam bahasa seorang aktifis HTI Yogyakarta, ibarat manusia,agama Negara saat ini adalah non-Islam (kafir). Dakwah mengajarkan amal Islam sepertisalat dan puasa bisa dilakukan kepada orang yang sudah beragama Islam. Namun ketika dakwah ditujukan kepada orang yang tidak beragama Islam, maka harus dimulai dengan menyeru untuk masuk Islam. Menyeru orang non-Islam untuk beramal sesuai ajaran Islam tidak ada gunanya sebelum dia masuk Islam terlebih dahulu. Demikian juga dengan Negara. Meski mayoritas penduduk Indonesia beragama Islam, tetapi karena Indonesia bukanlah Negara Islam, maka perubahan harus dimulai dengan menjadikan Indonesia Negara Islam. Perubahan yang sifatnya parsial (ișlahî) tidak akan ada gunanya selama Negara belum 'masuk' Islam. ${ }^{19}$

Dalam buku yang menjadi sumber penting panduan gerakan HT, Takättul al-Hizb, alNabhani i mengajarkan beberapa prinsip gerakan HTI yang mencerminkan karakter revolusionernya. Pertama, non-kooperasi. Hal ini tercermin dari kritik al-Nabhanai terhadap gerakan-gerakan Islam lain yang berjuang di area non-politik seperti pendidikan, perbaikan moral, ekonomi dan spiritual. Dengan terlibat dalam program-program demikian maka berarti akan turut melanggengkan sistem sekuler yang ada. HT memegang prinsip untuk tidak menerima "membantu mereka (sistem kufur) untuk melakukan perbaikan ekonomi, pendidikan, dan sosial. Hal ini karena dengan memberikan bantuan tersebut kepada para tiran akan memperpanjang umur sistem kufur yang mereka terapkan. $" 20$

Kedua, al-Nabhanī menekankan pada pentingnya menjaga kemurnian idoelogi dan

Nabhanani, Al- Shakhshiyah Al-Islāmiyah, vol. 1 (t.k.: t.p., t.t.), 45 .

19 Pernyataan ini disampaikan oleh aktifis HTI Yogyakarta, Ir. Wahyu WD, "Metode Mewujudkan Islam Rahmatan Lil Alamin,” Pidato, dalam Halaqah Islam Rahmatan Lil Alamin "Bersinergi Mewujudkan Islam Penebar Rahmah" (Diselenggarakan HTI Yogyakarta di Gedung Teatrikal UIN SUKA Yogyakarta, 08 November 2009).

${ }^{20}$ Hizbut Tahrir, Structuring of Party (Takattul elHizb) (London: Al-Khilafah Publications, 2001). sikap non-kompromi. ${ }^{21}$ Karena itu HT menerapkan proses rekruitmen berjenjang yang sangat ketat. Ini karena model gerakan HT mirip model vanguard ala Lenin yang menekankan peran partai sebagai pemimpin intelektual massa. ${ }^{22}$ Dukungan atau partisipasi dari massa tidak mesti diharapkan dalam bentuk keanggotaan, tetapi lebih berupa dukungan pemikiran dan moral. Karena itu HT membutuhkan kader-kader militan yang teguh dan konsisten, yang meski jumlahnya tidak besar tetapi karena konsistensi dan militansinya diyakini akan berpengaruh dalam mobilisasi dukungan publik.

Ketiga, berbeda dari gerakan revolusioner pada umumnya yang menggunakan strategi kekerasan dan teror, al-Nabhanī menekankan pada pentingnya partai menjaga gerakan dalam koridor non-kekerasan. Hal ini didasarkan pada pemahaman bahwa jihad yang dipahami sebagai qitāl (perang) hanya bisa dijalankan atas komando khalifah. Selama daulah khilafah belum terbentuk, maka jihad tidak boleh dijalankan oleh individu atau kelompok. Prinsip ini juga mengikuti metode perjuangan Rasulullah padafase Mekah, saat Rasulullah masih berjuang dalam konteks negara kafir. Yang dilakukan Rasulullah adalah perlawanan nonkekerasan untuk mendelegitimasipenguasa dan sistem kufur yang ada. Selain itu, prinsip ini bisa jadi dimaksudkan untuk menjaga strategi revolusi-berjenjang HTI. Berhadapan dengan negara, aksi kekerasan hanya akan memberi legitimasi bagi represi yang akan menghambat agenda revolusi-berjenjang.

\footnotetext{
${ }^{21}$ Taqiyuddin Al-Nabhani, The System of Islam (Nị̣am Al Islām) (London: Al Khilafah Publications, 2002), 74.

${ }^{22}$ Dalam karya monumentalnya, What is to $\mathrm{Be}$ Done, Vladimir Lenin mengalihkan model perjuangan revolusi kaum proletar ala Karl Marx yang fokus pada massa kaum pekerja, kepada perjuangan yang menekankan pada mobilisasi kelompok intelektual yang mempunyai disiplin tinggi. Bagi Lenin massa akan mudah digerakkan kalau pejuang revolusi telah menguasai kaum intelektual yang mempunyai komitmen dan terdidik secara ideologis atau yang disebut vanguard.
} 
Jenjang revolusi HTI dilakukan dalam tiga tahap. Pertama adalah pembinaan (tatqiif) yang bertujuan untuk menghimpun kaderkader inti (vanguard). Kedua, setelah kaderkader inti terbentuk, maka dilakukan dakwah secara terbuka berinteraksi dengan umat ( tafá'ul ma'a al-ummah) yang bertujuan ganda berupa delegitimasi sistem dan kekuasaan kufur dan mobilisasi dukungan publik dan kekuatan strategis, termasuk membangun ketidakpercayaan publik terhadap sistem yang ada. Tujuan ganda ini dilakukan melalui beberapa kegiatan termasuk (a) membongkar makar kekuatan anti-Islam (kashful khuttāth), (b) aktivitas politik dalam pengertian kritik atas kebijakan-kebijakan pemerintah (kifah siyashî), (c) perang pemikiran (shira' al-fikr), dan (d) pembelaan atas kepentingan umat (tabannì masalih al-ummah). ${ }^{23}$

Ketiga, jika dukungan publik sudah cukup kuat yang ditopang oleh dukungan dari pihakpihak yang mempunyai kekuatan seperti militer, tokoh politik dan tokoh masyarakat ( $a h l$ al-quwwah), maka HT meyakini proses peralihan kekuasaan dan sistem (revolusi) tidak akan terbendung. Meski dalam sejarah alNabhani pernah terlibat dalam percobaan kudeta di Jordania, para aktifis HTI menyangkal banwa kudeta akan menjadi pilihan. Seorang aktifis HTI di Yogyakarta menyebut jalan revolusi HTI jalan ketiga, sebagai alternatif terhadap perjuangan parlementer dan kudeta. Tidak jelas strategi jalan ketiga ini akan diwujudkan; tetapi salah satu pimpinan pusat HTI membayangkan proses perubahan HTI bisa mirip dengan apa yang terjadi dalam proses kejatuhan Soeharto, yakni lewat tekanan publik di luar mekanisme demokrasi.

Sejak muncul di Indonesia pada awal tahun 1980an, HTI mulai menapaki jenjang kedua (tafául ma'a al-ummah) pada tahun sekitar awal tahun 2000an. Perkembangan HTI bisa dibilang menyalip gerakan-gerakan Islam lain

23 Dari buku yang diterjemahkan dari tulisan pendirinya, Taqiyuddin al-Nabhani, HTI secara detil menjelaskan strategi untuk mengembalikan khilafah dalam buku berjudul Hizbut Tahrir Indonesia, Strategi Dakwah Hizbut Tahrir, Pustaka Thariqul Izzah, Bogor, 1997. seperti MMI dan FPI. HTI kini mempunyai kantor di hampir seluruh wilayah di Indonesia, dari tingkat provinsi hingga kecamatan. HTI juga mempunyai kemampuan mobilisasi dan logistik (keuangan) yang cukup besar. Pada tahun 2001 dan 2007 HTI mampu menghadirkan puluhan ribu massa dari berbagai daerah di Jakarta. Show of power ini berlanjut. Pada Juli 2009, HTI berhasil menggelar Musyawarah Ulama Nasional (MUN) yang mengumpulkan sekitar 6000 tokoh Muslim dari seluruh Indonesia di gedung tennis Indoor Senayan. Beberapa orang yang diundang mengaku HTI menyediakan tiket pesawat dan akomodasi untuk acara di Jakarta. Program serupa dilakukan organisasi sayap mahasiswa HTI Gema Pembebasan, dengan menggunakan nama Badan Koordinasi Lembaga Dakwah Kampus, yang pada 18 Oktober 2009 lalu mengumpulkan sekitar 4000 aktifis mahasiswa Islam dari berbagai wilayah di Indonesia dalam acara Kongres Mahasiswa Islam Indonesia (KMII) di depan Basket Hall, Senayan Jakarta. Selain itu, HTI juga kerap membuat program seminar dan diskusi temu tokoh secara serentak di berbagai daerah di hotelhotel dan tempat publik lainnya yang tentunya memerlukan biaya yang tidak sedikit. Di Yogyakarta, tokoh-tokoh HTI bahkan mengelola Sekolah Tinggi Ekonomi Islam yang membebaskan biaya pendidikan bagi seluruh mahasiswa.

Meski demikian konsistensi HTI pada jalur revolusi nampaknya tidak selalu konstan. Pada era sekitar 2007 hingga pertengahan 2008, HTI nampak akomodatif terhadap gerakangerakan Islam yang bersifat reformis (ișlāhî̀). Hal ini terutama tercermin dari pernyataan juru bicara HTI yang menyatakan bahwa HTI akan memperkokoh NKRI, sistem republik yang bertentangan dengan ideologi khilafah. Lebih lanjut Yusanto juga mengindikasikan terbukanya kemungkinan HTI berpartisipasi dalam pemilu. HTI ikut mempelopori berdirinya Forum Umat Islam yang perjuangannya bersifat iṣlăhi. Bahkan menjelang pemilu 2009, HTI menyelenggarakan diskusi yang mendorong terbentuknya poros Islam atau koalisi partai-partai Islam untuk mengu- 
sung calon presiden yang memperjuangkan syariat Islam. ${ }^{24} \mathrm{Hal}$ ini tentunya bertentangan dengan prinsip non-kooperasi dan non-partisipasi yang diajarkan al-Nabhanī.

Pada pertengahan 2009, pimpinan HTI nampaknya mulai melakukan evaluasi atas aktivitas-aktivitas yang dianggap merusak kemurnian dan konsistensi ideologi HTI. Ini terlihat dari keputusan HTI menarik diri dari FUI yang membuat salah satu tokoh penting HTI yang pernah menjadi ketua umum, Muhammad Al-Khattat, keluar (atau dikeluarkan) dari HTI. Al-Khattat memilih perjuangan lewat FUI selain mendirikan organisasi baru bernama Hizbud Dakwah Islami. Sejak itu, nampaknya HTI mulai menapaki kembali jalan revolusi-damai-berjenjang.

\section{Demokrasi: Peluang dan Tantangan Islam Politik}

Ketiga model gerakan Islam politik di atastentunya tidak akan bisa menghindar dari dialektika dengan konteks demokrasi di Indonesia. Demokrasi adalah peluang sekaligus tantangan bagi gerakan sosial. Masa depan ketiga model gerakan di atas akan ditentukan oleh bagaimana mereka bernegosiasi dengan proses politik, dan tidak semata-mata berpendirian pada doktrin gerakan. Kebebasan politik dalam sistem demokrasi seperti Indonesia selalu menjadi dambaan gerakan Islam politik. Di banyak negara gerakan Islam terhambat oleh sistem politik totalitarian atau demokrasi semu yang represif. Namun demikian bukan berarti demokrasi selalu menjadi kabar baik gerakan Islam politik yang antidemokrasi.

Berkat kebebasan politik di Indonesia, salah satu pencapaian penting Islam politik di Indonesia adalah terjadinya proses penguraian (breakdown) ikatan-ikatan keagamaan lama (traditional), terutama NU dan Muhammadiyah, yang selama ini menjadi benteng karakter moderat Islam di Indonesia. Gerakangerakan Islam politik baru 'merangsek' ke dalam lingkaran Islam mainstream (arus

\footnotetext{
${ }^{24}$ Yusanto, Ismail, "Syariah adalah Masa Depan Indonesia,” Suara Islam, 22 Juli 2008.
}

utama) dan mulai mengaburkan batas-batas komunal Islam mainstream. Cerita tentang anak-anak muda dan bahkan tokoh NU dan Muhammadiyah terus terdengar. Penelitian Masykur tentang fenomena perpindahan orang NU ke HTI menunjukkan terjadi kecenderungan terjadinya dis-orientasi di kalangan anak muda NU. Corak keIslaman NU dianggap biasa-biasa saja dan tidak mempunyai konsep perjuangan yang jelas. ${ }^{25}$ Hal ini bertolak belakang dengan tawaran organisasiorganisasi Islam politik seperti HTI dan Tarbiyah yang menawarkan perangkat ideologi dan panduan yang sederhana dan mudah dipahami.

Faktor internal lain yang menyebabkan pudarnya batas komunal Islam mainstream adalah melemahnya peran sosial NU dan Muhammadiyah. Di kalangan Muhammadiyah hal ini misalnya ditunjukkan oleh terbatasnya akses ke lembaga pendidikan dan rumah sakit Muhammadiyah akibat biaya yang mahal. Di kalangan NU perilaku elitis dan politis sebagian pimpinan NU telah mengalihkan mereka dari peran pemberdayaan masyarakat. NU yang diharapkan dapat memperkuat perannya sebagai penjaga Islam moderat di Indonesia memiliki kelemahan dalam program-program sosial yang mendekatkan masyarakat dan menyentuh langsung kebutuhan umat di tingkat bawah. Sementara pesantren yang selama ini menjadi lokus utama peran sosial NU perlahan-lahan mulai terpisah dari masyarakat. Pesantren-pesantren besar mulai terbawa arus politik, sementara pesantrenpesantren kecil yang lebih dekat dengan masyarakat kekurangan sumberdaya.

Sebagai ilustrasi, dalam satu perbincangan dengan pengurus MWC NU di satu kecamatan di Jawa Timur seorang pengurus mengeluh: "Dulu jama'ah datang ke kantor NU untuk memberikan sumbangan, sekarang diantara

\footnotetext{
${ }^{25}$ Masykur, "Fenomena Perpindahan Orang NU ke Komunitas HTI di Serang Banten," dalam Dialektika Teks Suci Agama: Strukturasi Makna Agama dalam Kehidupan Masyarakat, ed. Irwan Abdullah (Yogyakarta: Pustaka Pelajar dan Sekolah Pascasarjana UGM, 2008), 163-188.
} 
mereka hanya datang ke kantor NU ketika ada pembagian sumbangan., 26

Namun demikian bukan berarti gerakan Islam politik akan dengan mudah menaklukkan demokrasi. Banyak teoritisi demokrasi berpengaruh seperti Seymor M. Lipset dan Anthony Dawns, meyakini demokrasi mempunyai mekanisme yang akan meminggirkan gerakan radikal. Hal ini karena demokrasi memberikan beragam jalan bagi penyaluran konflik dan aspirasi politik. Kecenderungan politik selalu mengikuti arus utama elektorat yang umumnya bersifat 'median' atau moderat. ${ }^{27}$ Revolusi terjadi ketika tidak ada jalan lain. Dalam bahasa Alan Dawley, "demokrasi adalah kain kafan bagi kaum revolusioner." ${ }^{28}$ Kegagalan terus menerus politik Islam dalam pentas politik Indonesia bisa jadi bukti nyata kekuatan moderasi demokrasi.

Fakta memudarnya batas komunal antara yang moderat dan yang radikal sebagaimana disebut di atas adalah hasil dari mekanisme demokrasi yang juga bisa menjadi tantangan bagi mobilisasi gerakan radikal Islam politik. Untuk memperluas dukungan ke segmensegmen umat Islam yang beragam, gerakan politik Islam dituntut untuk menyimpan sementara agenda yang bersifat radikal. FUI adalah contoh pergumulan politik Islam untuk memperluas jangkauan pengaruh. Karena ideologi dan agenda politik di dalamnya yang beragam, aksi FUI selama ini hanya terbatas pada tuntutan-tuntutan non-radikal yang menjadi titik temu beragam segmen umat Islam, seperti isu pembubaran Ahmadiyah, perlawanan terhadap pluralisme, dan dukungan terhadap Perda 'bernuansa syariat'.

\footnotetext{
${ }^{26}$ Perbicangan dengan Muzakkir, tokoh pemuda NU di Lamongan, Jawa Timur pada 22 April 2012.

27 Lihat, Lipset, Seymor M. Political Man: The Social Base of Politics (Garden City: Doubledy, 1960), dan Dawns,Anthony, Economic Theory of Democracy (New York: Harper, 1957). Lihat juga R. Mitchels, Political Parties: A Sociological Studies of Oligarchical Tendencies of Modern Democracy (New Jersey: Transaction Publishers, 1999).

${ }^{28}$ Dawley,Alan, Class and Community: The Industrial Revolution in Lynn (Cambridge: Harvard University Press, MA, 1976), 70.
}

\section{Deliberative Democracy sebagai Solusi Islam Politik}

Demokrasi menjadi medan persaingan merebut dukungan publik antara kekuatan radikal dan non-radikal. Kodrat politik adalah mengikuti kecenderungan mainstream. Selama Islam moderat masih menjadi arus utama, maka kekuatan politik akan menjauh dari agenda radikal. Sebaliknya, ketika aspirasi radikal mengambil alih arus utama, maka dengan sendirinya kekuatan politik akan turut mengusung agenda radikal.

Umumnya negara demokrasi tidak mengalami perubahan politik yang bersifat radikal atau revolusioner. Tetapi bukan berarti tidak ada demokrasi yang tumbang oleh kekuatan revolusioner. Republik Weimar Jerman adalah negara demokrasi yang ditumbangkan oleh kekuatan totaliter anti-demokrasi Nazi pada tahun 1930an. Menurut Sheri Berman, Partai Pekerja Nasional Sosialis Jerman (NSDP) berhasil memanfaatkan proses demokrasi untuk menggulingkan demokrasi. NSDAP awalnya adalah partai kecil di parlemen Jerman. Ketika Republik Weimar Jerman mengalami krisis ekonomi dan demokrasi mengalami disfungsi, NSDAP berhasil memobilisasi dukungan publik yang kemudian menjadi basis kekuatan bagi Hitler untuk memaksakan perubahan konstitusi, yang memberikan kekuasaan penuh atas dirinya. ${ }^{29}$

Artinya, demokrasi yang fungsional akan menjadi penangkal mobilisasi politik Islam radikal. Dalam bahasa yang populer di literatur demokrasi saat ini demokrasi yang fungsional disebut demokrasi yang memberi hasil (deliberative democracy). Demokrasi bersifat deliberative ketika kebijakankebijakan yang keluar dari institusi demokrasi mencerminkan suara atau kepentingan publik sehingga berdampak langsung terhadap kehidupan sehari-hari masyarakat. Dalam definisi Lars Hasselblad Torres "deliberative

\footnotetext{
${ }^{29}$ Berman, Sheri, "Islamism, Revolution and Civil Society," Perspectives on Politics 1, no. 2 (June 2003). Lihat juga tulisan Berman lain tentang proses kejatuhan Republik Weimar Jerman, Sheri Berman, "Civil Society and the Collapse of Weimar Republic," World Politics 49, no. 3 (April 1997): 401-29.
} 
democracy strengthens citizen voices in governance by including people of all races, classes, ages and geographies in deliberations that directly affect public decisions. As a result, citizens influence -- and can see the result of their influence on -- the policy and resource decisions that impact their daily lives and their future." ${ }^{30}$

Karena itu proses mendorong demokrasi agar bersifat deliberative bisa terbantu oleh peran lembaga-lembaga survei, penelitian, forum-forum rembug warga, dan lain-lain yang mendekatkan aktor-aktor dalam lembaga demokrasi dengan rakyat, sehingga keputusankeputusan yang mereka ambil mewakili kepentingan publik.

Kesenjangan antara perilaku elit politik yang menjadi aktor demokrasi dengan kepentingan publik akan melemahkan demokrasi dan mengakibatkan instabilitas. Kondisi demikian akan memberi legitimasi terhadap argumentasi anti-demokrasi gerakan politik Islam radikal. Keberhasilan Nazi menggulingkan demokrasi secara parlementer bisa menjadi pelajaran bagi keberlangsungan demokrasi dan karakter moderat Islam di Indonesia. Jika demokrasi mengutamakan prosedur dan partai politik gagal dalam menyalurkan aspirasi yang berdampak langsung terhadap kehidupan riil publik, maka akan membuka kesempatan bagi politik Islam radikal untuk mengambil alih peran ini. Gagasan sebagian tokoh politik Islam untuk mendirikan partai politik Islam ideologis yang konsisten menjadi oposisi parlemen bisa menjadi opsi gerakan politik Islam untuk memecah kebuntuan (breakthrough) Islam politik dalam pentas politik Indonesia.

Untuk memelihara karakter moderat Islam di Indonesia perlu upaya membangun demokrasi yang deliberative yang memperkuat peran kelompok-kelompok Islam mainstream dalam proses politik, pengambilan kebijakan

30"Deliberative Democracy FAQ," diakses pada 3 Juni 2012, www.deliberative-democracy.net. Penjelasan lebih detail tentang 'deliberative democracy', lihat James Bohman dan William Rehg, eds., Deliberative Democracy: Essays on Reason and Politics (London: The MIT Press, 1997). dan peran nyata dalam pemerintahan dan sektor non-pemerintah yang berdampak langsung terhadap kesejahteraan mereka. Dengan langkah ini, sistem politik demokrasi akan terjaga secara stabil sekaligus mereduksi kekuatan radikal dalam arena politik dan memperkuat peran sosial kekuatan moderat di kalangan umat Islam

\section{SIMPULAN}

Demokratisasi di Indonesia telah menunjukkan proses pematangan yang kecil sekali kemungkinannya akan berbalik mundur. Karena itu peluang terjadinya perubahan secara revolusioner dengan menggulingkan demokrasi dan menggantinya dengan negara Islam hampir mustahil terjadi. Ketiga model jalan politik Islam yang dipaparkan di sini adalah alternatif terhadap jalan revolusioner; masing memiliki tujuan dan metode yang berbeda. Jalan yang paling ekstrim ditempuh oleh HTI yang berusaha menentang sistem tetapi tidak cara konfrontasi. Melalui strategi revolusi damai berjenjang HTI ia memilih masuk ke dalam sistem, membangun relasi dengan aktor-aktor di dalam kekuasaan dengan harapan akan bisa memobilisasi dukungan untuk mengganti sistem dari dalam. Meskipun HTI menunjukkan kemajuan di sejumlah tempat tetapi kecil sekali jalan ini akan berhasil. Sebaliknya, belakangan HTI justru menghadapi pukulan balik karena dianggap antiPancasila.

Sementara model jalan Islam politik yang kedua berusaha memanfaatkan sistem demokrasi untuk mendorong Islamisasi dalam skala luas misalnya dengan mengusung agenda legislasi shariah Islam. Model ini bisa dicontohkan oleh sejumlah gerakan dan partai politik seperti PKS, FPI, FUI, MMI dan sejumlah organisasi serupa dengan nama yang beragam di tingkat daerah. Model kedua ini tidak akan merubah tatanan politik yang ada tetapi bisa berpengaruh besar dalma merubah lanskap sosial keagamaan yang bisa mempengaruhi aktor-aktor politik untuk menerima agenda Islamisasi ruang publik.

Kekuatan terbesar politik Islam menempuh jalan reformis sebagaimana direpresentasikan 
oleh NU, Muhammadiyah dan MUI. Meski demikian kekuatan-kekuatan dalam lingkup kategori ini seringkali berkontestasi satu sama lain baik secara ekonomi, sosial maupun politik. Kontestasi ini menyediakan ruang kosong dalam mempengaruhi sikap massa Muslim yang tidak jarang diisi oleh kelompokkelompok yang menempuh kedua jalan yang lebih radikal. Selain itu isu-isu tertentu seperti Kristenisasi dan aliran sesat seringkali menciptakan irisan-irisan yang mengkaburkan batas antara kelompok-kelompok dengan jalan politik yang berbeda. Dinamika akan menjadi struktur kesempatan politik (political opportunity structure) yang akan menentukan masa depan warna Islam politik di Indonesia.

\section{DAFTAR PUSTAKA}

Ahnaf, Mohammad Iqbal. "Anticipating Changing Landscape of Muslims." Jakarta Post. 2009.

Al-Nabhani, Taqiyuddin. Al- Shakhshiyah AlIslamiyah. Vol. 1. t.k.: t.p., t.t.

- The System of Islam (Nidam Al Isläm). London: Al Khilafah Publications, 2002.

Ash, Timothy Garton. We the People: Revolution of 89, Witness in the Warsaw, Budapest, Berlin, and Prague. London: Penguin Books, 1990.

Boland. B.J. The Struggle of Islam of Islam in Modern Indonesia. Martinus Nijhoff, The Hague, 1982.

Berman, Sheri. "Civil Society and the Collapse of Weimar Republic." World Politics 49, no. 3 (1997): 401-29.

-. "Islamism, Revolution and Civil Society." Perspectives on Politics 1, no. 2 (2003).

Bohman, James, dan William Rehg, eds. Deliberative Democracy: Essays on Reason and Politics. London: The MIT Press, 1997.

Dawley, Alan. Class and Community: The Industrial Revolution in Lynn. Cambridge: Harvard University Press, MA, 1976.

Dawns, Anthony. Economic Theory of Democracy. New York: Harper, 1957.

"Dewan Syariat Kota." Al-Wa'ie. Surabaya,
2005.

Effendy, Bahtiar. "Islamic parties have long been at an impasse." Jakarta Post. 2009.

Farouki, Suha Taji. Fundamental Quest: Hizb al-Tahrir and the Search for Islamic Caliphate. UK: Grey Seals Books, 1997.

Lipset, Seymor M. Political Man: The Social Base of Politics. Garden City: Doubledy, 1960.

Masykur. "Fenomena Perpindahan Orang NU ke Komunitas HTI di Serang Banten." Dalam Dialektika Teks Suci Agama: Strukturasi Makna Agama dalam Kehidupan Masyarakat, diedit oleh Irwan Abdullah. Yogyakarta: Pustaka Pelajar dan Sekolah Pascasarjana UGM, 2008.

Mitchels, R. Political Parties: A Sociological Studies of Oligarchical Tendencies of Modern Democracy. New Jersey: Transaction Publishers, 1999.

Noer, Deliar. Gerakan Modern Islam di Indonesia 1900-1942. Jakarta: LP3ES, 1980.

Roy, Oliver. Globalized Islam: The Search for a New Ummah. Columbia: Columbia University Press, 2004.

Salim, Arskal. Challenging Secular State: The Islamization of Law in Modern Indonesia. Honolulu: University of Hawai Press, 2008.

Tahrir, Hizbut. Hizb al-Tahrir. t.k.: Hizbut Tahrir, 1953.

- Structuring of Party (Takattul elHizb). London: Al-Khilafah Publications, 2001.

WD, Ir. Wahyu. "Metode Mewujudkan Islam Rahmatan Lil Alamin." Pidato. Dalam Halaqah Islam Rahmatan Lil Alamin "Bersinergi Mewujudkan Islam Penebar Rahmah.” Penyelenggara HTI Yogyakarta: di Gedung Teatrikal UIN SUKA Yogyakarta, 2009.

Yusanto, Ismail. "Syariat adalah Masa Depan Indonesia." Suara Islam, 2008.

\section{Internet}

"Deklarasi Darunnajah," 2008. Diakses tanggal 03 Juni 2012. http://hizbuttahrir.or.id/2008/08/02/deklarasi- 
darunnajah/.

"Deliberative Democracy FAQ." Diakses pada 3 Juni 2012. www.deliberativedemocracy.net.

“Hasil Pemilu 2014," 2014. Diakses tanggal 5 Juli 2015. http://www.pemilu.com/hasilpemilu-2014/.
"Hasil Suara Nasional Pemilu 2009," 2009.

Diakses tanggal 5 Juli

2015.http://nasional.kompas.com/read/200 9/05/09/22401496/inilah.hasil.akhir.perole han.suara.nasional.pemilu.

\section{Wawancara}

Tokoh HTI. Wawancara oleh M. Iqbal Ahnaf. Malang, 28 Oktober 2009. 